\title{
Impact assessment of rural PPP MaaS pilots
}

\author{
Jenni Eckhardt* (D), Arttu Lauhkonen and Aki Aapaoja
}

\begin{abstract}
The purpose of this paper is to present the impact assessment results of Mobility as a Service pilots based on public-private collaboration. In the pilots, companies and local and regional stakeholders joined their expertise to experiment with different ways of organizing mobility services in rural areas. The pilots included demandresponsive transport and integrated transport of different user groups and combining trips that include customers paying themselves and those being publicly subsidized. In addition to the call centre service, a smartphone application was introduced. The impact assessment of these pilots spans individual/user, business/organizational and societal levels. The main findings include improved accessibility of transport services in rural areas and resource efficiency in terms of improved occupancy rates of vehicles, reduced driven kilometres and emissions, and cost savings for the public sector.
\end{abstract}

Keywords: Mobility as a Service, Public-private partnership, Rural, Impact assessment

\section{Introduction}

Rural areas face challenges organizing transport services due to long distances, sparse population and narrow flows of people and goods. Public transport (PT) services are often poor and heavily subsidized. The current trend of urbanization and demographic changes, along with a growing number of elderly people, will further complicate matters-especially regarding statutory social and health service transportation and service transport targeting e.g. the elderly. Furthermore, the public sector's ongoing struggles with cost savings and environmental targets create additional challenges to organizing transport services in rural areas.

Rural Mobility as a Service (MaaS) could improve the accessibility of remote areas and offer new and efficient transport services by integrating different types of transportation and exploiting digitalization [5]. MaaS is also expected to have positive effects on the environment, such as a modal shift from car to public transport and sharing services, an increase in multimodal trips, resource efficiency, and decreased emissions [22]. Public actor involvement is required in rural areas where market-based public transport and other transport

* Correspondence: jenni.eckhardt@vtt.fi

VIT Technical Research Centre of Finland Ltd., P.O.Box 1100, FI-90571 Oulu, Finland services are not viable [3]. Collaboration between the public and private sectors has been recommended for MaaS $[4,7,27,29]$. Public-private partnership (PPP) refers to cooperation between public-private actors in which they jointly develop services and share the risks, costs and resources connected to these services [38].

As there is a lack of evidence on the impacts of PPP MaaS, this paper addresses the following question: what are the impacts of PPP rural MaaS? The query spans individual/user, business/organizational, and societal levels. The results are based on MaaS pilots conducted in public-private collaboration. In the pilots, companies, regional and local stakeholders joined their expertise to experiment with different ways of organizing mobility services in rural areas. The pilots include demandresponsive transport (DRT) and integrated transport services for different user groups, combining trips for selfpaying and subsidized customers. In addition, a smartphone application was introduced for self-paying customers.

The motivation and aims of the regional and local authorities to pilot new ways of organizing mobility services included cost savings for the public sector, improved service level for residents, and reduced environmental impact. In addition, the pilots were geared to prepare for future reform: while these were in the 
planning stage, preparations were also being made for reforms in the areas of health, social services and regional government. According to the plans, the responsibility for organizing public health and social services would come under regional rather than municipal control, as would regional public transport services that are currently organized by the Centre for Economic Development, Transport and the Environment, from the beginning of 2021. However, this was not accepted by the government and a new reform is under preparation.

The paper is structured as follows: A review of the literature describes the MaaS concept and relevant discussions on PPP. Next is a description of the adopted methodology, followed by case descriptions and their impact assessment results. The results concentrate on individual/user level but include summaries relating to business/organizational and societal levels. The results are discussed and followed by concluding remarks.

\section{Literature review}

The literature review covers MaaS, concentrating on rural mobility and the impacts of MaaS, and PPP discussions. The public sector thrives on the societal targets of MaaS, making public and private sector collaboration essential.

MaaS is a concept of user-oriented and integrated mobility services (e.g. $[1,7,16,21,23,25,37])$. The components of MaaS integration can be divided into Shared mobility, Booking/Ticketing and Multimodal traveller information [23]. Multimodality is a common feature of MaaS (see e.g. [4]), which is also relevant in rural areas, but rural MaaS can be more a matter of combining different services and user groups than modes, since accessibility is the key concern [3]. Eckhardt et al. [3] have defined rural MaaS as "mobility of people and goods on a one-stop-shop principle consisting of various user groups and integrated transport services" (p. 41). Transport has an important role related to rural social exclusion [13]. Transport disadvantage may cause transport poverty, leading to inaccessibility to essential goods and services and resulting in social exclusion [24]. As public transport is often insufficient in rural areas, people without a car have much poorer access to key services [36], and centralization of essential services requires regional travelling [31]. Rural MaaS solutions could include e.g. on-demand transport and sharing services $[5,17]$ and organized hitchhiking [30], as well as integrating social and health service and school transportation with market-based transportation [5, 35]. Goods deliveries can also be integrated into MaaS (e.g. [4, 8, 19, 25]). This is considered more relevant for rural areas due to long distances, sparse population and narrow flows of people and goods [4].
MaaS is expected to have several positive effects beyond environmental impacts. The UbiGo MaaS trial in Sweden showed several changes in attitude: participants became less positive towards the private car and more so towards alternative modes such as carsharing, bus/ tram, and bike sharing [34]. MaaS can improve accessibility to transport and have a positive impact on total travel cost per individual/household [22]. It can also improve the efficiency of existing transport services and public resources [29]. Many indicators of impact assessment have been connected to MaaS. Examples include emissions, efficiency and accessibility (e.g. [1, 26]), modal share, travel cost, congestion, journey quality and quality of life (e.g. [20]), as well as business models, public health, and social inclusion (e.g. [1]). Table 1 presents an impact assessment framework including key performance indicators (KPIs) on individual/user, business/ organizational and societal levels related to environmental, economic and social impact areas [22].

PPP has been recommended for MaaS. Public-private partnership refers to "co-operation of some durability between public and private actors in which they jointly develop products and services and share risks, costs and resources which are connected with these products or services" ([38], p. 598). PPPs can have benefits for both the public and private sectors including e.g. improved value for money $[2,9,14,28]$ and combining public and private expertise efficiently [10]. In addition, PPP may improve existing public sector practices and generate more creative and innovative approaches [9]. PPPs' potential challenges include e.g. complex planning and contracts, and lack of public sector capacity and experience $[9,28]$.

MaaS requires stronger collaboration between the public and private sectors, and new mobility services should be developed in collaboration with the private sector and local and transport authorities supporting the city and regional transport priorities and policies [29]. MaaS has the potential to improve the efficiency of existing transport services and public resources $[5,7,29]$. The involvement of public actors will likely lead to integration of societal goals into MaaS [3]. The public sector's role has also been recognized as important in removing legislative barriers to MaaS (e.g. $[4,15,33])$. However, new models and tools for public-private collaboration are needed to effectively govern the development of sustainable MaaS [32]. Large-scale deployments of MaaS require modifications to current business models and business relations, making publicprivate open innovation challenging [33].

\section{Methodology}

The results are based on a case study consisting of multiple cases and both qualitative and quantitative data [6]. The case studies presented here were conducted in two 
Table 1 Impact assessment framework [22]

\begin{tabular}{|c|c|c|c|c|}
\hline Level & KPIs & Environmental & Economic & Social \\
\hline \multirow[t]{6}{*}{ Individual/ user level } & Total number of trips made & $\mathrm{x}$ & & $\mathrm{x}$ \\
\hline & Modal shift (from car to PT, to sharing, to ...) & $x$ & & \\
\hline & Number of multimodal trips & $x$ & & \\
\hline & Attitudes towards PT, sharing, etc. & $x$ & & \\
\hline & Perceived accessibility to transport & & & $x$ \\
\hline & Total travel cost per individual/household & & $x$ & $x$ \\
\hline \multirow[t]{6}{*}{ Business/organizational level } & Number of customers & & $x$ & \\
\hline & Customer segments (men/women, young/old, ...) & & $x$ & $x$ \\
\hline & Collaboration/partnerships in value chain & & $x$ & \\
\hline & Revenues/turnover & & $x$ & \\
\hline & Data sharing & & $x$ & \\
\hline & Organizational changes, changes in responsibilities & & & \\
\hline \multirow[t]{5}{*}{ Societal level } & Emissions & $x$ & & \\
\hline & Resource efficiency (roads, vehicles, land use, ...) & $x$ & $x$ & \\
\hline & Citizens' accessibility to transport services & & $x$ & $x$ \\
\hline & Modification of vehicle fleet (electrification, automation) & $x$ & & \\
\hline & Legal and policy modifications & $x$ & $x$ & $x$ \\
\hline
\end{tabular}

pilot regions in Finland including rural areas: the city of Porvoo in Eastern Uusimaa (Case 1) and the cities of Ylöjärvi and Sastamala in the Tampere region (Case 2). The research methodology (Fig. 1) includes a literature review, workshops, surveys, interviews, data collection and result consolidation. The research is mainly qualitative, and quantitative data includes end-user surveys and data on rides provided by the digital service providers involved in the study (Kyyti Group, Vinka and Sitowise). Quantitative data is limited, and its aim is to support the qualitative analysis.

The literature review covered MaaS and PPP discussions. Regional workshops were conducted separately in Cases 1 and 2 and included local and regional authorities and transport and digital service providers involved in the pilots. The Case 1 workshop also included endusers. First, similar types of stakeholders (users, transport service providers, digital service providers, or local/ regional authorities) reflected on the impacts of their MaaS experience on themselves and/or their organizations. Then, as a whole group, the participants discussed the impacts gleaned from the smaller groups. Finally, the participants discussed how to achieve positive and avoid negative impacts of mobility services. Transcripts were made of each discussion to improve reliability. The main aim of the workshop was to generate discussion on experiences, expectations and ideas on piloted mobility services, as well as to increase understanding between different stakeholders involved in the pilots. More detailed data was gathered through surveys and interviews (Table 2).

End-user opinions were gathered using surveys. Users were asked about their experiences of both the piloted services and the application, and their attitudes towards demand-responsive and integrated services. In Case 2, end users included self-paying customers using a mobile app, statutory social and health service transport (SHST) customers, and service transport (called PALI) customers. Perceptions of the organizations involved in the pilots (Table 3) were gathered by thematic interviews conducted similarly on a semi-structured basis that were recorded to improve reliability [39]. Questions dealt with e.g. positive and negative experiences regarding the pilot and the service concept, stakeholder collaboration, and recommendations for future development based on the lessons learned. 
Table 2 Data collection

\begin{tabular}{llll}
\hline Case & Number of customers/ trips /driven routes & Data collection method & Number of respondents or workshop participants \\
\hline 1 & $69 / 363 / 281$ & Closed-ended survey (web) & 15 \\
& & Pilot stakeholder workshop & 9 \\
2 & Closed-ended survey & 33 \\
& $-19442 / 5727$ & $\cdot$ SHST (phone) & $\cdot 8$ \\
& - PALI (printed) & $\cdot 22$ \\
& - App (web) & $\cdot 3$ \\
$1 \& 2$ & Pilot stakeholder workshop & 16 \\
\hline & Semi-structured interviews & 9 \\
\hline
\end{tabular}

Quantitative data, in addition to surveys, was retrieved from the digital platform created by the companies involved in the pilots. All the data, both qualitative and quantitative, was further processed case by case in project group work meetings for the final conclusions. The collected data was compared to the KPI framework (Table 1) and synthesized. The synthesis was reviewed and validated by the interviewed organizations excluding the transport service provider.

\section{Case descriptions}

Case 1 included a DRT service called Kyläkyyti, operated by minibuses, and ran from January to May 2019. The pilot covered a narrow area from the centre of Porvoo northward to the southern parts of Askola. It was selected to include rural areas where no public transport existed in the evenings, as the city wished to offer a service targeted at young people travelling to and from leisure activities. This area has roughly 3000-4000 inhabitants, or 120 inhabitants per $\mathrm{km}^{2}$ on average. The pilot included a rural area close to an urban area according to the Finnish urban-rural classification (Fig. 2).

This DRT service ran solely on a mobile app, and cost 3 euros for trips of less than $10 \mathrm{~km}$ and 5 euros for longer trips. For regular PT customers, Kyläkyyti was free. Even though Case 1 did not include real MaaS-like integration, this development is seen as an enabler for future MaaS. The app included long-haul PT, biking and walking routes, and could include local PT routes and ticketing in the future.

Case 2 integrated different user groups, services and vehicles within the same mobility system, and ran from
March to October 2019, starting gradually with different services. Kuru (city of Ylöjärvi) and Vammala (city of Sastamala) were selected as pilot areas because of their sparse population and long distances. There is also very limited public transport in these areas. Kuru consists mainly of sparsely populated rural areas, and Vammala includes rural heartland (Fig. 3). Kuru has approximately 2600 inhabitants and 50 SHST customers, while Vammala has approximately 16,000 inhabitants and 300 SHST customers.

Case 2 consisted of DRT, shared transport of different user groups, and combining trips that included both self-paying and publicly subsidized customers (see Fig. 4). Before the pilot, SHST customers used a (shared) taxi. During the pilot, these customers were integrated with the PALI service; thus, the vehicle could be either a taxi or a PALI minibus. In addition, they could share the vehicle with PALI and other self-paying customers.

PALI is a minibus DRT service open to all but designed to serve primarily the elderly and mobilityimpaired. The driver assists passengers if needed. For PALI customers, the main change was that before the pilot they ordered the service by calling the minibus directly. During the pilot, they contacted a call centre and the transport service was provided either by a PALI minibus or SHST taxi.

Before the pilot, no dedicated service existed for other customers. During the pilot, a DRT service called Kyläkyyti was offered through a mobile app. The idea was to integrate other user groups with a public transport fare (varying from 3 to 7.5 euros) primarily on PALI minibuses, but also with existing statutory SHST taxi rides. A

Table 3 Interviewed organizations

\begin{tabular}{lll}
\hline Local and regional authorities & City of Porvoo & Tampere region \\
& City of Ylöjärvi & City of Sastamala \\
Service providers & Tuomi Logistiikka Oy & Kyyti Group Ltd. \\
& Vinka Oy & Sitowise Oy \\
\hline
\end{tabular}




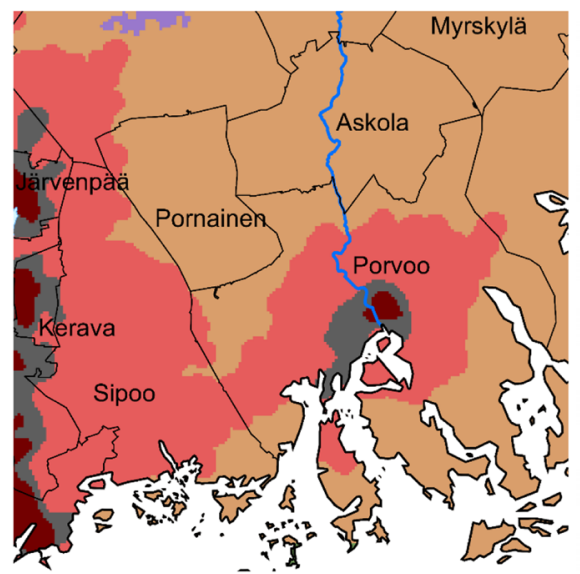

\section{Urban-rural classification}

Inner urban area

Outer urban area

Peri-urban area

Local centre in a rural area

Rural area close to urban area

Rural heartland area

Sparsely populated rural area

Fig. 2 Urban-rural classification of Porvoo [11]

self-paying customer could not initiate a statutory SHST taxi ride, which would have been too costly for the public sector.

A digital platform was created by the companies participating in the project (Kyyti Group, Vinka and Sitowise) to optimize routes and integrate rides. The platform integrated rides ordered by the app and call centre within the same system. Tuomi Logistiikka is an in-house company from several municipalities in the region and is responsible for procuring and organizing e.g. SHST services, including the call centre service.

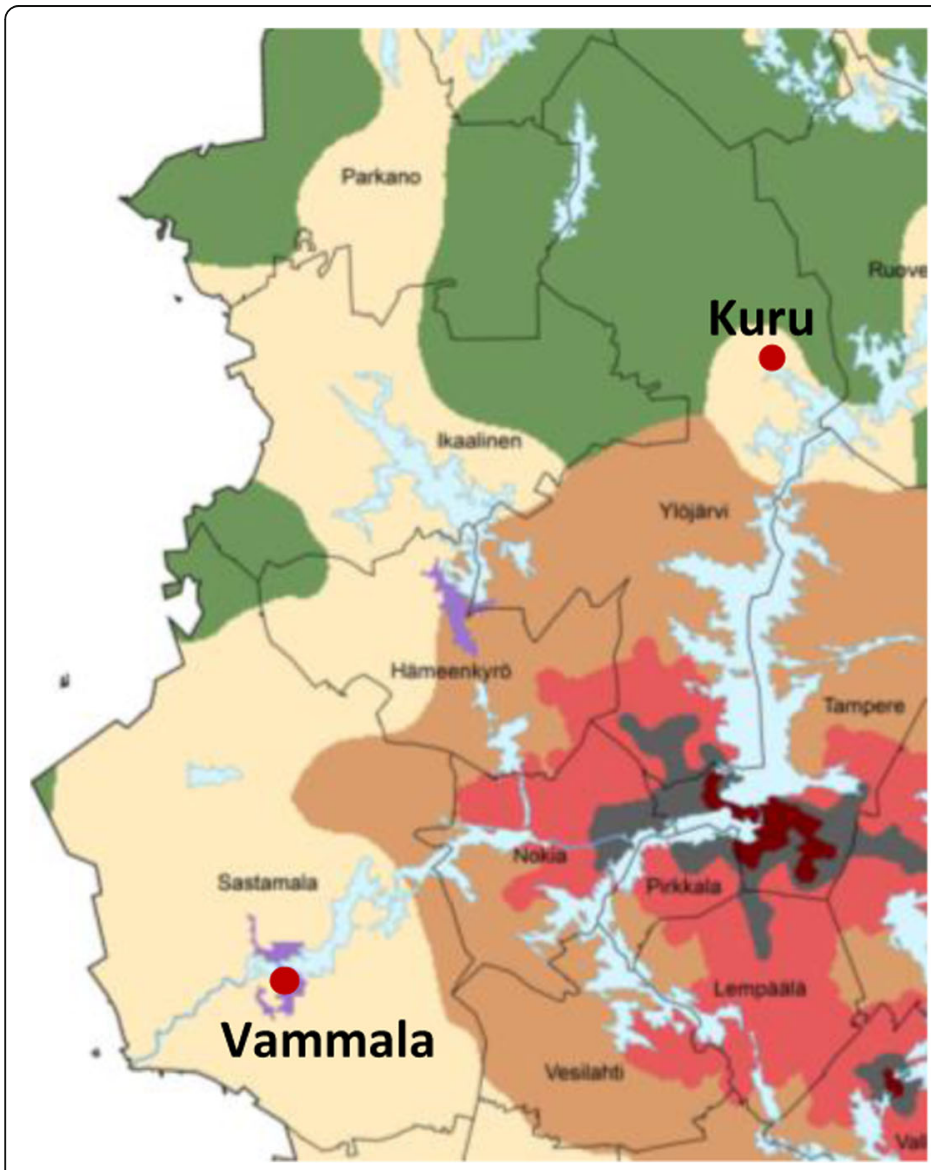

Urban-rural classification

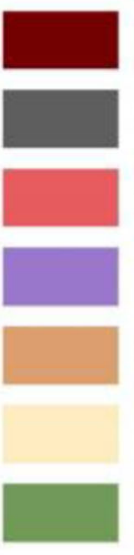

Inner urban area

Outer urban area

Peri-urban area

Local centre in a rural area

Rural area close to urban area

Rural heartland area

Sparsely populated rural area

Fig. 3 Urban-rural classification of Kuru and Vammala [11] 

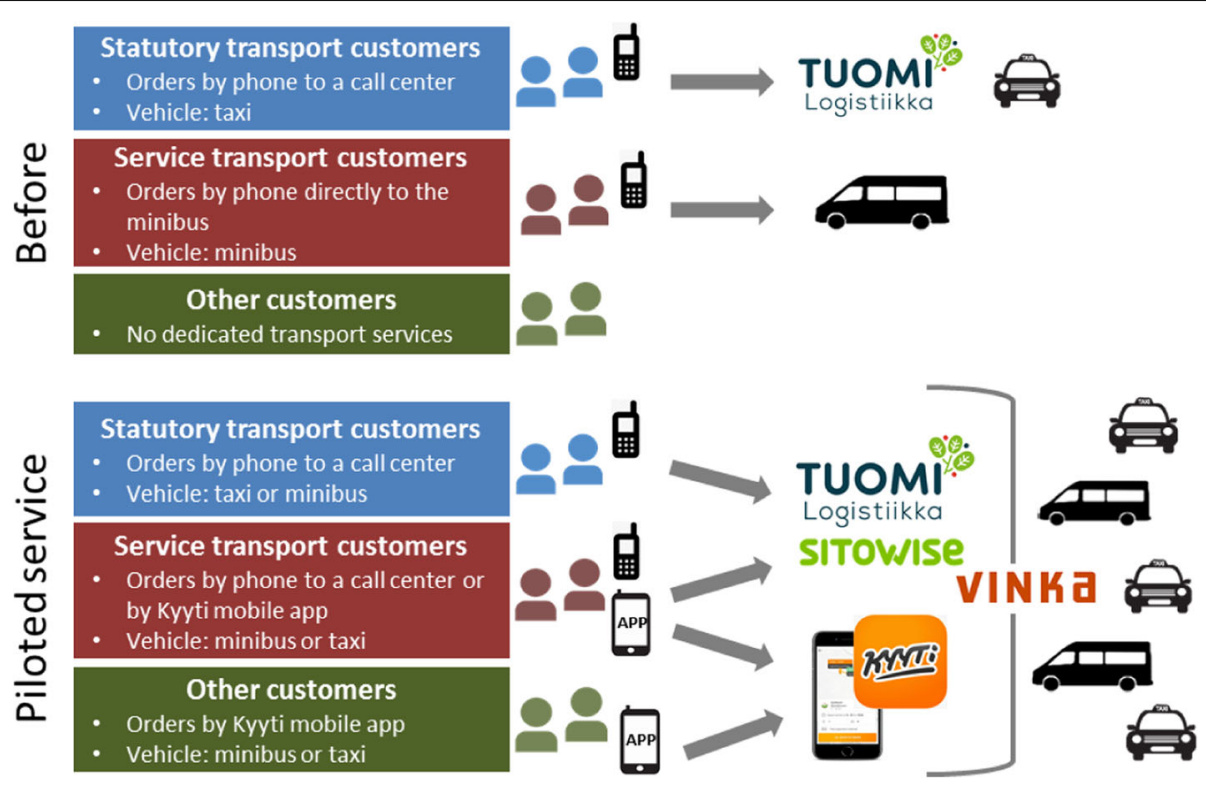

Fig. 4 Transport services for different user groups before and during the Case 2 pilot

\section{Results}

\subsection{Case 1}

During the pilot, 69 customers made a total of 363 trips. Fifteen customers responded to the survey, of whom two thirds were women and a third men. The average age of the respondents was 39 years, but it should be noted that some respondents bought tickets for their children, making the average user age younger. The average household size of the respondents was 4.6 people. On average, a household owns 2.53 cars and 3.47 bicycles (Fig. 5).

Kyläkyyti was mainly used for leisure activities (66.7\%), as targeted, and for school and work trips (33.3\%) (Fig. 6). There were many reasons for using the service, the main one being that the respondent's own or family car was not available (80\%) (Fig. 7). Without the Kyläkyyti service, in many cases the trip would have involved travelling by car as a passenger (66.7\%), and some (26.7\%) of the respondents said they would not have made the trip at all (Fig. 8). Note that these questions included multiple options, and responses in total exceeded $100 \%$.

The respondents had found Kyläkyyti mainly through Facebook/Twitter/friends (46.7\%) and the local newspaper (40\%). Information on the service was also found on the city's website (6.7\%) and home-delivered brochure (6.7\%). Users were delighted with the service, giving it a Net Promoter Score (NPS) of 93. The respondents mostly preferred a DRT $(73.3 \%)$ over traditional pubic transport based on schedules and fixed routes $(0 \%)$, and $26.7 \%$ could not say.

Table 4 is based on quantitative data (survey results and data from the digital service providers), shaded in grey, and qualitative data (interviews, workshop). In summary, the most important aspects at individual/user level include accessibility. Many Kyläkyyti trips were made because no other options were available at the time. At business/organizational level, being a new business is the main advantage in the short term, and since

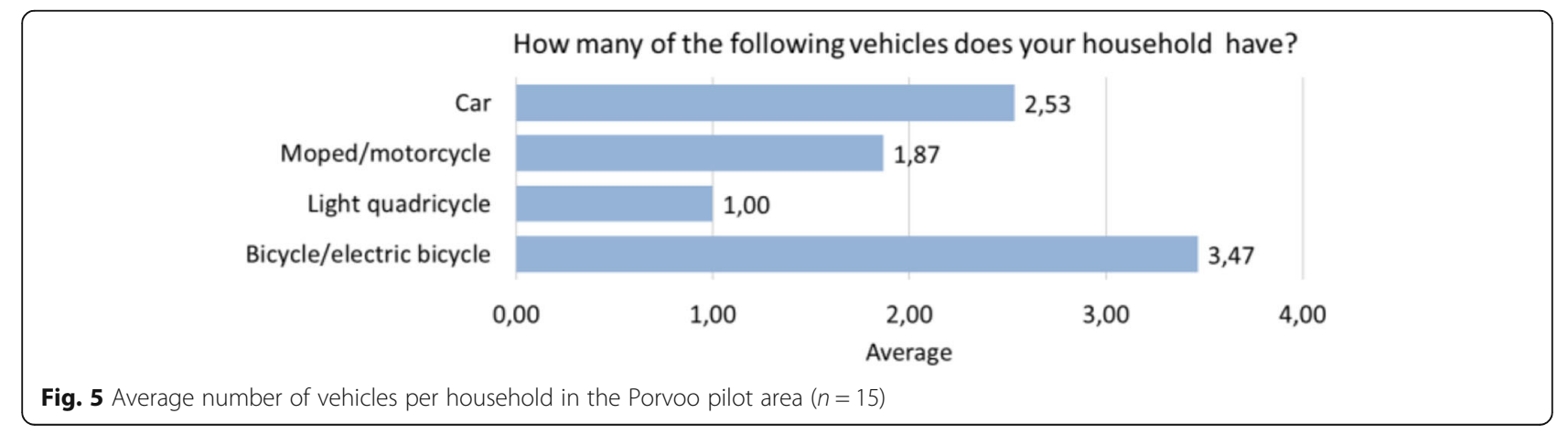




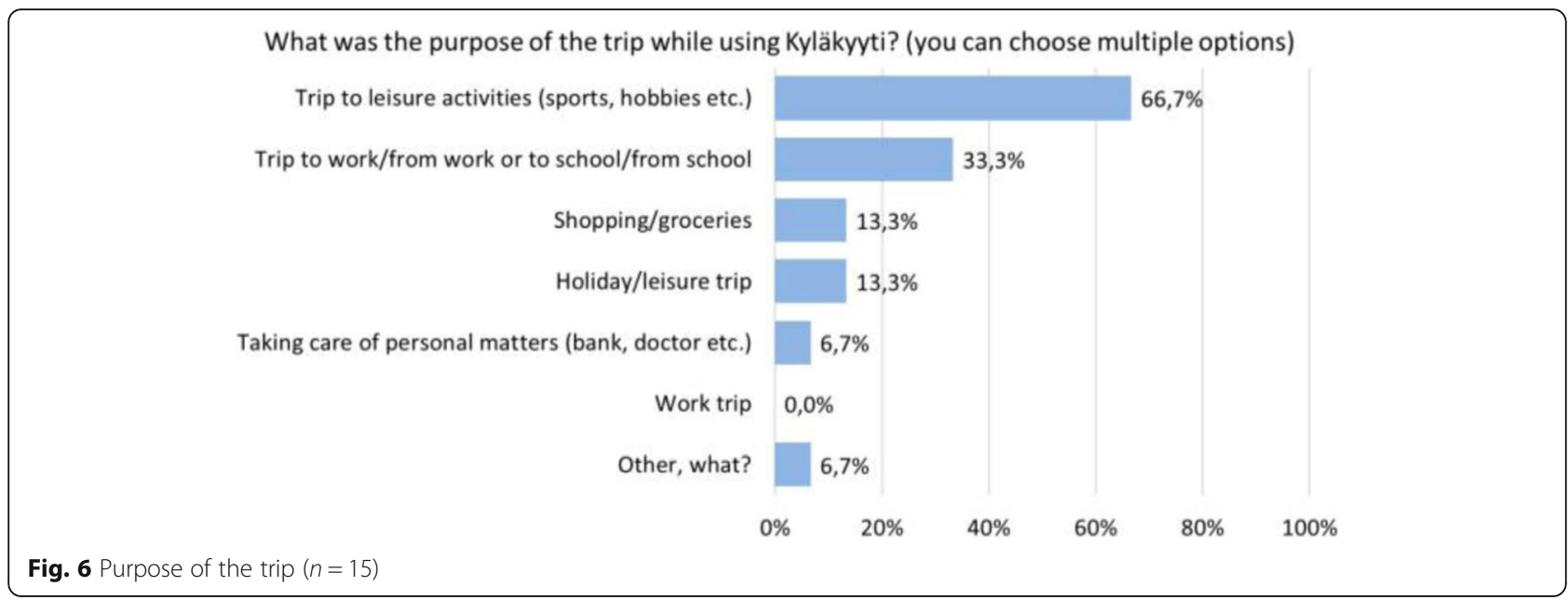

the service is set to continue beyond the pilot funding, the digital service providers will likely increase their turnover as well. In the longer term, the pilot initiated broader development of DRT services in the region. The main societal impacts will result from greater accessibility to transport services. The pilot also improved resource efficiency.

\subsection{Case 2}

Twenty-two service transport customers responded to a survey, $81 \%$ of whom were women. The average age of the respondents was 76 years. The respondents were happy with the arrival time of the ride and availability of the service (Fig. 9), but not with the waiting time on the phone. They also preferred scheduled transport with fixed routes (79\%) over DRT (16\%), which is almost opposite to the younger respondents' views of Kyläkyyti in Case 1.

Eight SHST customers responded to a questionnaire, the average age of whom was 75 years. Attitudes towards integration were generally neutral and positive, but some negative feedback was received regarding longer waiting times for a ride. Nearly all the respondents considered cost savings for the public sector, environmental friendliness, and new mobility opportunities in sparsely populated areas to be good reasons for integrating services and user groups similar to those in the pilot.

There was a total of 16 Kyläkyyti orders by mobile app, mainly involving a PALI minibus. Three customers responded to a questionnaire. They were middle-aged and two of them were women. They used the service mainly for shopping/buying groceries but also for other personal matters. Without the Kyläkyyti service they would have made the trip using different transport modes: bicycle, car, taxi or public transport. The main reasons for using the service were curiosity and affordability of the service. The respondents were generally satisfied with the service and app and would mostly prefer a DRT service for their daily trips.

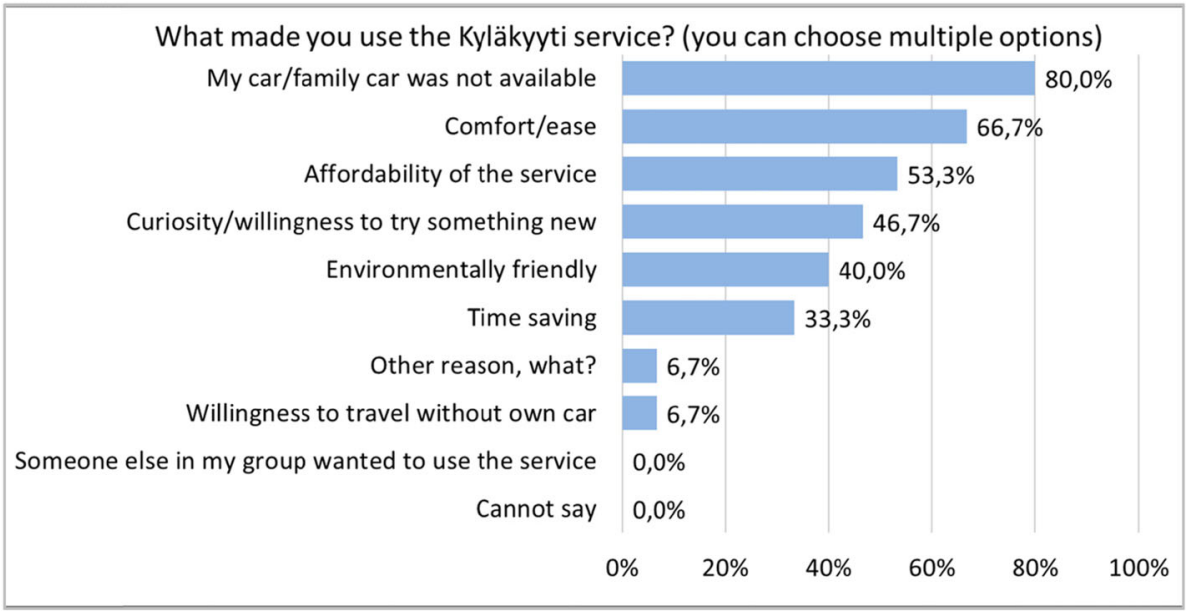

Fig. 7 Reasons for using Kyläkyyti $(n=15)$ 
How would the trip have been made without the Kyläkyyti service? (you can

choose multiple options)

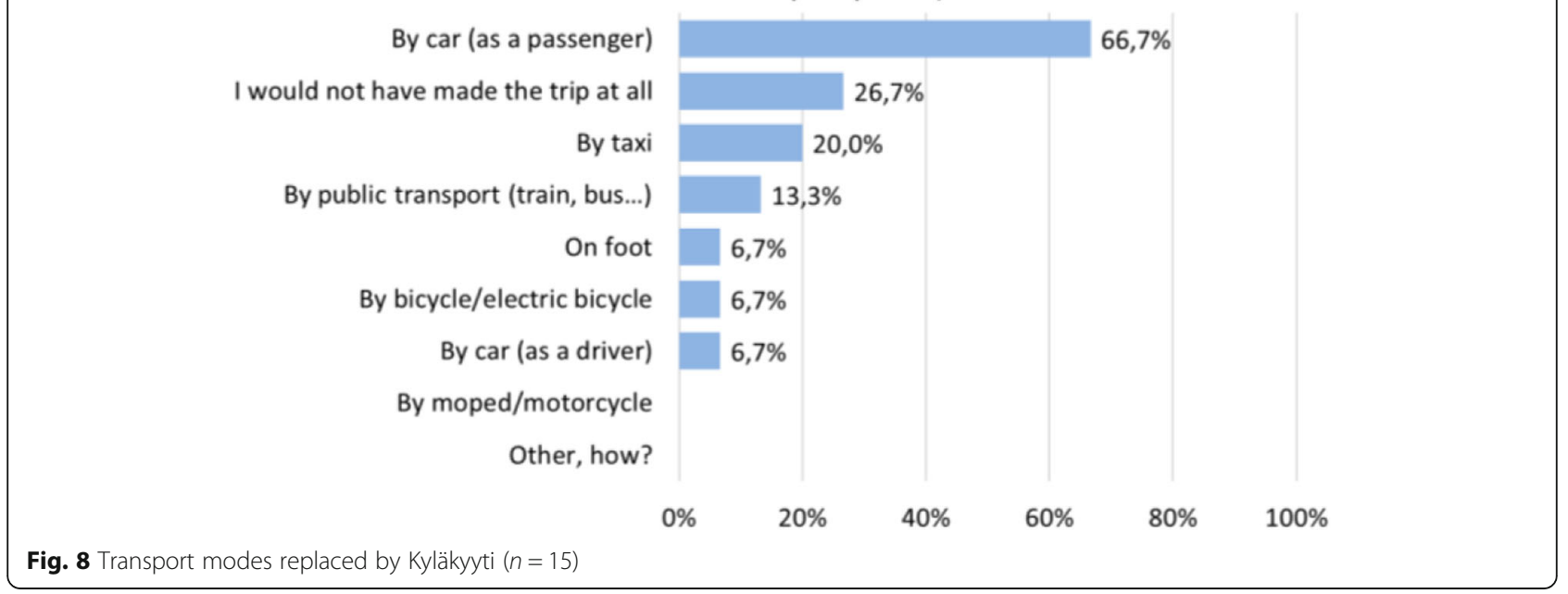

Impact assessment summary is presented in Table 5. It is based on qualitative data (interviews and workshop) and quantitative data (shaded in grey) provided by the digital service providers and based on surveys. There were nearly 6900 orders in total during the pilot, resulting in nearly 9500 passenger trips and over 5700 driven routes. The sharing degree was 1.65 , meaning that on average 1.65 persons shared a ride (passenger trips divided by driven routes). Compared to a situation without sharing, $7036 \mathrm{~km}$ of PALI and 3887 of taxi kilometres were saved, equivalent to $24.8 \%$ of driven PALI and $6.6 \%$ of driven taxi kilometres. However, there was no exact before-data on the pilot area, but pilot stakeholders estimated the integration to improve sharing clearly.

In summary, there were some benefits at individual/user level regarding modal shift. At business/organizational level, the pilot promoted regional mobility development and data sharing. The most significant benefits of the pilot were at societal level. This resulted in both reduced emissions and lower costs for the public sector. Integrating statutory SHST taxi rides, which are costly, and replacing taxi rides with the existing PALI minibus service resulted in lower average cost per customer. Resource efficiency was also improved through higher occupancy rates of vehicles. Accessibility was enhanced with a new service.

\section{Discussion}

Generally, MaaS in expected to offer a wide spectrum of market-based multimodal transport services on a onestop-shop principle, attracting people to use private cars less, which would result e.g. in lower emissions and congestion. However, urban and rural MaaS have some differences, and there are many ways to create MaaS services. Roughly, urban MaaS is multimodal and based on public transport complemented with additional services, while rural MaaS is based on integrating different services and user groups and using mainly ondemand and sharing services. The aim in urban areas is to reduce emissions and congestion, while in rural areas it is to improve accessibility and increase efficiency. While urban MaaS can be market-based, rural MaaS includes mainly subsidized transport, and cost savings for the public sector is the target rather than a profitable business. Public stakeholder involvement is also more crucial in rural MaaS, even though it is beneficial in cities too, in order to include societal and policy goals in MaaS. Even though MaaS is often developed from an urban perspective, rural mobility is gaining attention. Accessibility of rural areas is a concern for both people and businesses like tourism. In addition, the increasing costs of organizing statutory transport services are putting pressure on the public sector to rationalize their transport services. Environmental targets apply to rural areas as well. Integration of services and user groups assist in achieving all these targets. However, organizing integrated services is complex and requires collaboration. Multiple stakeholders are involved, both from the public and the private sector, and they might have different priorities and targets. For this reason, the public sector needs to take a strong role and lead the integration of public-private collaboration. Public stakeholders have different practices and rules, such as different principles for the co-payment of statutory transport services, which complicates integration when combining customers with different co-payment shares in the same system and rides. Thus, harmonization of rules and procedures would be recommended. Also, integrating different transport services requires resources, skill and willingness from the public sector to develop MaaS and procure services in a new way. Using in-house companies similar to Tuomi 
Table 4 Impacts of Case $1,(\uparrow)=$ increase, $(\downarrow)=$ decrease, $0=$ no change, n.a. $=$ no information available

\begin{tabular}{|c|c|c|c|}
\hline Level & KPI & $\begin{array}{l}\text { Increase/ } \\
\text { decrease }\end{array}$ & Comment \\
\hline \multirow{6}{*}{ 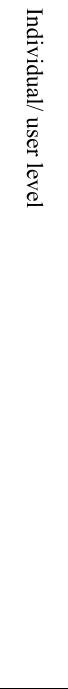 } & $\begin{array}{l}\text { Total number of trips } \\
\text { made }\end{array}$ & $\downarrow$ & The service reduced the need for parents to drive their children. \\
\hline & $\begin{array}{l}\text { Modal shift (from car to } \\
\text { PT, to sharing, to...) }\end{array}$ & $\uparrow$ & $\begin{array}{l}\text { Without the DRT service, } 66.7 \% \text { of the respondents would have } \\
\text { used a private car as a passenger and } 6.7 \% \text { as a driver. Note: } \\
\text { respondent could choose several options }\end{array}$ \\
\hline & $\begin{array}{l}\text { Multimodal trips, } \\
\text { combining different } \\
\text { modes of transport }\end{array}$ & n.a. & $\begin{array}{l}\text { The service did not offer travel chains. However, the app } \\
\text { included long-haul PT, walking and biking routes. }\end{array}$ \\
\hline & $\begin{array}{l}\text { Attitudes towards PT, } \\
\text { sharing, etc. }\end{array}$ & $\uparrow$ & $\begin{array}{l}\text { Respondents were extremely satisfied with the service (NPS 93) } \\
\text { and willing to continue using it. }\end{array}$ \\
\hline & $\begin{array}{l}\text { Perceived accessibility } \\
\text { to transport }\end{array}$ & $\uparrow$ & $\begin{array}{l}26.7 \% \text { would not have made the trip at all without Kyläkyyti. } \\
80 \% \text { chose Kyläkyyti because their car (or family car) was not } \\
\text { available. Note: respondent could choose several options }\end{array}$ \\
\hline & $\begin{array}{l}\text { Total travel cost per } \\
\text { individual/household }\end{array}$ & n.a. & $\begin{array}{l}73.3 \% \text { of the respondents strongly agreed and } 20 \% \text { agreed that } \\
\text { the trips were affordable. For over half of the respondents, the } \\
\text { affordability of the service played a role in using it. }\end{array}$ \\
\hline \multirow{7}{*}{ 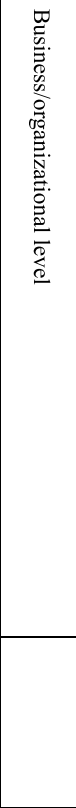 } & Number of customers & $\uparrow$ & $\begin{array}{l}\text { The new service pilot attracted } 69 \text { customers with } 363 \text { trips in } \\
\text { total. }\end{array}$ \\
\hline & Customer segments & n.a. & $\begin{array}{l}\text { Among the respondents: } \\
\text { - } 66.7 \% \text { were women, } \\
\text { - } 60 \% \text { were employed and } \\
26.7 \% \text { were students/schoolchildren, } \\
\text { - average age was } 39 \text { years } \\
\text { - } 66.7 \% \text { ordered rides for leisure activities, of which } 40 \% \\
\text { were ordered for their children. }\end{array}$ \\
\hline & $\begin{array}{l}\text { Collaboration/ } \\
\text { partnerships in value } \\
\text { chain }\end{array}$ & $\uparrow$ & The service was implemented in public-private collaboration. \\
\hline & Revenues/turnover & $\uparrow$ & $\begin{array}{l}\text { The service created new business for transport and digital } \\
\text { service providers. }\end{array}$ \\
\hline & Data sharing & $\uparrow$ & Digital service platform produced detailed data, which was \\
\hline & & & shared with the client (city). \\
\hline & $\begin{array}{l}\text { Organizational changes, } \\
\text { changes in } \\
\text { responsibilities }\end{array}$ & $\uparrow$ & $\begin{array}{l}\text { The pilot initiated the planning of a more extensive DRT } \\
\text { service. }\end{array}$ \\
\hline \multirow{5}{*}{ 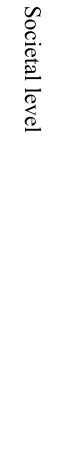 } & Emissions & n.a. & $\begin{array}{l}\text { The reduced use of private cars and optimization of routes } \\
\text { likely led to lower emissions. }\end{array}$ \\
\hline & Resource efficiency & $\uparrow$ & $\begin{array}{l}\text { The use of DRT was increased, replacing mostly private cars. } \\
\text { Route optimization also improved resource efficiency. }\end{array}$ \\
\hline & $\begin{array}{l}\text { Accessibility of the } \\
\text { public to transport } \\
\text { services }\end{array}$ & $\uparrow$ & $\begin{array}{l}\text { Kyläkyyti introduced a new door-to-door service in areas and at } \\
\text { times where no public transport was available and thus } \\
\text { improved accessibility. }\end{array}$ \\
\hline & $\begin{array}{l}\text { Modification of vehicle } \\
\text { fleet }\end{array}$ & 0 & $\begin{array}{l}\text { The pilot utilized the existing fleet. New software was } \\
\text { downloaded to driver displays. }\end{array}$ \\
\hline & $\begin{array}{l}\text { Legal and policy } \\
\text { modifications }\end{array}$ & n.a. & $\begin{array}{l}\text { Perceived need for improvement is related to the } \\
\text { interoperability of different travel card systems. }\end{array}$ \\
\hline
\end{tabular}




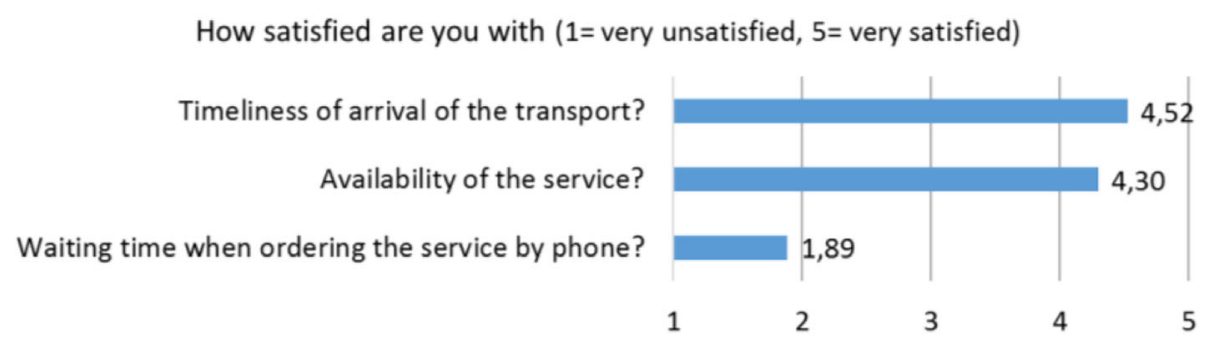

Fig. 9 Satisfaction with the service $(n=22)$

Logistiikka, which would have the required competence to procure and integrate the transport services of several municipalities, would be beneficial.

ICT infrastructure and digital literacy may cause challenges for rural MaaS. In Finland, data network coverage is comprehensive also in rural areas, enabling widespread use of digital services, while some countries may have inadequate data network coverage. Older, non-college educated inhabitants of remote areas belong to the demographic least likely to purchase MaaS [18]. The lack of digital literacy needs to be taken into account when developing rural MaaS, as not everyone has the possibility or knowledge to use apps. This is why Case 2 included a call centre service integrated with the digital system. Case 1, after the pilot period, continued the service while expanding the service area and introducing a call centre service, which improves inclusivity of the service.

The results are transferrable and relevant in other regions of Finland, and in rural areas of other countries as well. Differences and specific characteristics of each area should be considered when interpreting the results. The low number of users and survey/questionnaire respondents, as well as the short pilot period, might cause some inaccuracy in the results. The number of orders through the app remained low, especially in Case 2. It was observed during the pilot that SHST rides were often ordered very close to the time they were needed (minimum $1 \mathrm{~h}$ before), making integration challenging as the app could not propose these rides sooner. In both cases, marketing was considered insufficient and its role important to increase awareness of the service and attain new customers. Case 1 would have required many more customers in order to cover expenses. However, the service continued beyond the pilot, regardless of the costs, as it was in line with the city strategy including low-carbon mobility, digitalization of transport, and family-friendliness.

Despite the challenges, the pilots showed clear evidence of a positive impact, and there were no clear negative impacts even though some negative feedback was received in the surveys. In addition, similar results have been identified in other pilots, such as the Ylläs Around pilot which took place in 2016-2017 (Table 6) in Northern Finland (sparsely populated rural area), in the Ylläs ski resort area and between the airport and railway station. The pilot included multimodal transport services (buses, taxis and shared taxis) through a mobile app including payment and ticketing features. Twenty customers responded to the Ylläs Around survey [12]. Common to all these pilots is a modal shift and positive attitude from private cars to PT and sharing, as well as improved accessibility and resource efficiency. The pilots were organized in public-private collaboration, and they increased sharing of data and promoted further mobility development.

\section{Conclusions}

This paper set out to explore the impacts of PPP rural MaaS. The impact assessments of two pilots were presented and discussed. Both Case 1 and 2 included DRT services, and Case 2 also included the integration of different user groups and vehicles combining trips for selfpaying and subsidized customers. The aim of the pilots was to increase accessibility of the public to transport services and to reduce environmental impacts. In addition, Case 2 aimed at cost savings for the public sector.

The pilots fulfilled the set objectives and clearly show that DRT and integrated rural MaaS solutions have future potential. Case 1 resulted in a clear modal shift from private cars to DRT minibuses and better accessibility of transport services. Integration of services in Case $2 \mathrm{im}$ proved occupancy rates of vehicles and reduced kilometres driven and emissions. Integration of subsidized statutory transport rides resulted in cost savings for the public sector. A new service with a mobile app was created for self-paying customers, which improved the service level. Pilots improved collaboration and data sharing between stakeholders and created new business. Based on the results, it can be concluded that PPP rural MaaS can have major positive impacts at all levels: individual/user, business/organizational and societal.

This was the first time ever in Finland that integration of transport services similar to Case 2 was conducted. The successful integration forms a promising basis for future development. The pilots included limited geographical areas and services, and the duration of the pilots was short. For future research, more extensive pilots with a longer period would be needed. Successfully piloted services could be extended geographically, and new services 
Table 5 Impacts of Case $2(\uparrow)=$ increase, $(\downarrow)=$ decrease, $0=$ no change, n.a. $=$ no information available

\begin{tabular}{|c|c|c|c|}
\hline Level & KPI & $\begin{array}{l}\text { Increase/ } \\
\text { decrease }\end{array}$ & Comment \\
\hline \multirow{6}{*}{ 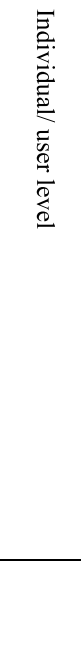 } & $\begin{array}{l}\text { Total number of trips } \\
\text { made }\end{array}$ & n.a. & $\begin{array}{l}\text { Probably no change in the number of PALI and SHST trips. } \\
\text { Insufficient data on private customers. }\end{array}$ \\
\hline & $\begin{array}{l}\text { Modal shift (from car } \\
\text { to PT, to sharing, ...) }\end{array}$ & $\uparrow$ & $\begin{array}{l}\text { The service increased sharing of statutory rides and shifted } \\
\text { slightly from cars (taxis and private cars) to shared rides. }\end{array}$ \\
\hline & $\begin{array}{l}\text { Multimodal trips, } \\
\text { combining different } \\
\text { modes of transport }\end{array}$ & n.a. & $\begin{array}{l}\text { The service did not offer travel chains. However, feeder } \\
\text { service to a public transport bus stop was offered. }\end{array}$ \\
\hline & $\begin{array}{l}\text { Attitudes towards PT, } \\
\text { sharing, etc. }\end{array}$ & $\uparrow$ & Attitudes towards sharing were neutral and mainly positive. \\
\hline & $\begin{array}{l}\text { Perceived } \\
\text { accessibility to } \\
\text { transport }\end{array}$ & n.a. & $\begin{array}{l}\text { The service level remained the same among PALI and SHST } \\
\text { customers. Data from private customers is not sufficient for } \\
\text { drawing conclusions. }\end{array}$ \\
\hline & $\begin{array}{l}\text { Total travel cost per } \\
\text { individual/household }\end{array}$ & n.a. & $\begin{array}{l}\text { Private customers found the fare very affordable, which } \\
\text { played a role in using it. }\end{array}$ \\
\hline \multirow{6}{*}{ 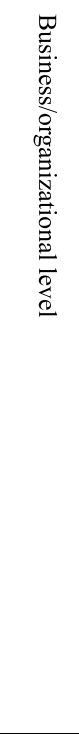 } & Number of customers & $\uparrow$ & Some new customers. \\
\hline & Customer segments & n.a. & $\begin{array}{l}\text { Among the respondents: } \\
\text { - } 81 \% \text { (PALI) and } 75 \% \text { (SHST) were women } \\
\text { - average age was } 76 \text { (PALI) and } 75 \text { (SHST) years }\end{array}$ \\
\hline & $\begin{array}{l}\text { Collaboration/ } \\
\text { partnerships in value } \\
\text { chain }\end{array}$ & $\uparrow$ & The service was implemented in public-private collaboration. \\
\hline & Revenues/turnover & n.a. & $\begin{array}{l}\text { It is uncertain whether the service will continue as piloted, } \\
\text { thus whether there will be new business for digital service } \\
\text { providers. }\end{array}$ \\
\hline & Data sharing & $\uparrow$ & $\begin{array}{l}\text { The digital services platform produced detailed data, which } \\
\text { was shared with the clients (cities). }\end{array}$ \\
\hline & $\begin{array}{l}\text { Organizational } \\
\text { changes, changes in } \\
\text { responsibilities }\end{array}$ & $\uparrow$ & $\begin{array}{l}\text { The pilot promoted the development of regional passenger } \\
\text { transport services. }\end{array}$ \\
\hline \multirow{5}{*}{ 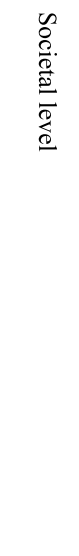 } & Emissions & $\downarrow$ & $\begin{array}{l}\text { Driven kilometres were reduced by } 12.6 \% \text {, thus } 10923 \mathrm{~km} \text {, } \\
\text { and } \mathrm{CO}_{2} \text { emissions by } 2.6 \text { tonnes }{ }^{1} \text {. }\end{array}$ \\
\hline & Resource efficiency & $\uparrow$ & $\begin{array}{l}\text { Integration of services improved occupancy rates of vehicles, } \\
\text { reduced driven kilometres and emissions equally, and resulted } \\
\text { in cost savings for the public sector. }\end{array}$ \\
\hline & $\begin{array}{l}\text { Accessibility of the } \\
\text { public to transport } \\
\text { services }\end{array}$ & $\uparrow$ & $\begin{array}{l}\text { A new service was created for private customers where public } \\
\text { transport does not exist. }\end{array}$ \\
\hline & $\begin{array}{l}\text { Modification of } \\
\text { vehicle fleet }\end{array}$ & 0 & $\begin{array}{l}\text { The pilot used the existing fleet. New software was } \\
\text { downloaded to driver displays. }\end{array}$ \\
\hline & $\begin{array}{l}\text { Legal and policy } \\
\text { modifications }\end{array}$ & n.a. & $\begin{array}{l}\text { The need for a GDPR interpretation guide and harmonized } \\
\text { procedures for SHST (e.g. co-payment) was recognized. }\end{array}$ \\
\hline
\end{tabular}

${ }^{1}$ Estimated by the LIPASTO unit emission database (http://lipasto.vtt.fi/yksikkopaastot/indexe.htm) using $\mathrm{CO}_{2}$ emissions of $168 \mathrm{~g} / \mathrm{km}$ for a passenger car (2016, urban driving) and $278 \mathrm{~g} / \mathrm{km}$ for a minibus (6 t delivery lorry, empty, urban driving, EURO VI). 
Table 6 Comparison of Case 1, Case 2 and Ylläs Around impacts, $(\uparrow)=$ increase, $(\downarrow)=$ decrease, $0=$ no change, n.a. $=$ no information available (adopted partly from [12])

\begin{tabular}{|c|c|c|c|c|}
\hline \multirow[t]{2}{*}{ Level } & \multirow[t]{2}{*}{ KPI } & \multicolumn{3}{|l|}{ Services } \\
\hline & & Case 1 & Case 2 & Ylläs Around \\
\hline \multirow[t]{6}{*}{$\begin{array}{l}\text { Individual/ user } \\
\text { level }\end{array}$} & Total number of trips made & $\begin{array}{l}\downarrow \\
\text { Parents gave fewer rides to their } \\
\text { children. }\end{array}$ & n.a. & $\begin{array}{l}\text { n.a. } \\
\text { Travelling without a car } \\
\text { became easier. }\end{array}$ \\
\hline & $\begin{array}{l}\text { Modal shift (from car to PT, } \\
\text { to sharing, to...) }\end{array}$ & $\begin{array}{l}\uparrow \\
\text { From private cars to DRT. }\end{array}$ & $\begin{array}{l}\uparrow \\
\text { Increased sharing and slight } \\
\text { change from cars to shared rides. }\end{array}$ & $\begin{array}{l}\uparrow \\
\text { Increased use of PT (63\%) } \\
\text { and reduction of car use } \\
(71 \%) \text {. }\end{array}$ \\
\hline & $\begin{array}{l}\text { Combining different modes } \\
\text { of transport }\end{array}$ & $\begin{array}{l}\text { n.a. } \\
\text { The service did not offer travel chains. }\end{array}$ & $\begin{array}{l}\text { n.a. } \\
\text { The service did not offer travel } \\
\text { chains. }\end{array}$ & $\begin{array}{l}\uparrow \\
\text { Bus and (shared) taxi on } \\
\text { the same ticket. }\end{array}$ \\
\hline & $\begin{array}{l}\text { Attitudes towards PT, } \\
\text { sharing, etc. }\end{array}$ & $\begin{array}{l}\uparrow \\
\text { Respondents were extremely satisfied } \\
\text { and willing to continue the use of the } \\
\text { service. }\end{array}$ & $\begin{array}{l}\uparrow \\
\text { Neutral and positive attitudes } \\
\text { mainly. }\end{array}$ & $\begin{array}{l}\uparrow \\
\text { Respondents were willing } \\
\text { to continue using the } \\
\text { service. }\end{array}$ \\
\hline & $\begin{array}{l}\text { Perceived accessibility to } \\
\text { transport }\end{array}$ & $\begin{array}{l}\uparrow \\
\text { Major improvement in accessibility. }\end{array}$ & n.a. & $\begin{array}{l}\uparrow \\
\text { Respondents found that } \\
\text { the service simplified their } \\
\text { mobility. }\end{array}$ \\
\hline & $\begin{array}{l}\text { Total travel cost per } \\
\text { individual/ household }\end{array}$ & $\begin{array}{l}\text { n.a. } \\
\text { Respondents found the fare very } \\
\text { affordable, which played a role in using } \\
\text { the service. }\end{array}$ & $\begin{array}{l}\text { n.a. } \\
\text { Respondents found the fare very } \\
\text { affordable, which played a role in } \\
\text { using the service. }\end{array}$ & $\begin{array}{l}\downarrow \\
\text { Respondents (60\%) found } \\
\text { their travel expenses to be } \\
\text { lower due to the service. }\end{array}$ \\
\hline \multirow{6}{*}{$\begin{array}{l}\text { Business/ } \\
\text { organisational } \\
\text { level }\end{array}$} & Number of customers & $\begin{array}{l}\uparrow \\
69 \text { customers. }\end{array}$ & $\begin{array}{l}\uparrow \\
\text { Some new customers. }\end{array}$ & $\begin{array}{l}\uparrow \\
106 \text { customers. }\end{array}$ \\
\hline & Customer segments & $\begin{array}{l}\text { n.a. } \\
\text { Average age } 39 \text { years. Mostly women. }\end{array}$ & $\begin{array}{l}\text { n.a. } \\
\text { Elderly people. Mostly women. }\end{array}$ & $\begin{array}{l}\text { n.a. } \\
\text { Average age } 43.5 \text { years. } \\
\text { Mostly men. }\end{array}$ \\
\hline & $\begin{array}{l}\text { Collaboration/ partnerships } \\
\text { in value chain }\end{array}$ & $\begin{array}{l}\uparrow \\
\text { Public-private collaboration. }\end{array}$ & $\begin{array}{l}\uparrow \\
\text { Public-private collaboration. }\end{array}$ & $\begin{array}{l}\uparrow \\
\text { Public-private collaboration. }\end{array}$ \\
\hline & Revenues/ turnover & $\begin{array}{l}\uparrow \\
\text { New business for transport and digital } \\
\text { service providers. }\end{array}$ & $\begin{array}{l}\text { n.a. } \\
\text { New business for digital service } \\
\text { providers is possible, but uncertain. }\end{array}$ & $\begin{array}{l}\uparrow \\
\text { Positive economic effect for } \\
\text { transport service providers. }\end{array}$ \\
\hline & Data sharing & $\begin{array}{l}\uparrow \\
\text { Data sharing between digital service } \\
\text { providers and the client (city). }\end{array}$ & $\begin{array}{l}\uparrow \\
\text { Data sharing between digital service } \\
\text { providers and the client (city). }\end{array}$ & $\begin{array}{l}\uparrow \\
\text { MaaS platform improved } \\
\text { data sharing by stakeholders. }\end{array}$ \\
\hline & $\begin{array}{l}\text { Organizational changes, } \\
\text { changes in responsibilities }\end{array}$ & $\begin{array}{l}\uparrow \\
\text { Initiated larger development of the DRT } \\
\text { service. }\end{array}$ & $\begin{array}{l}\uparrow \\
\text { Promoted the development of } \\
\text { regional passenger transport } \\
\text { services. }\end{array}$ & $\begin{array}{l}\uparrow \\
\text { Initiated larger development } \\
\text { of mobility services in the Ylläs } \\
\text { area. }\end{array}$ \\
\hline \multirow[t]{5}{*}{ Societal level } & Emissions & $\begin{array}{l}\text { n.a. } \\
\text { Reduced use of private cars and } \\
\text { optimization of routes. }\end{array}$ & $\begin{array}{l}\downarrow \\
\text { Driven kilometres and } \mathrm{CO}_{2} \\
\text { emissions reduced. }\end{array}$ & $\begin{array}{l}\downarrow \\
\text { Reduced use of private cars. }\end{array}$ \\
\hline & $\begin{array}{l}\text { Resource efficiency (roads, } \\
\text { vehicles, land use, ...) }\end{array}$ & $\begin{array}{l}\uparrow \\
\text { Increased use of DRT and route } \\
\text { optimization. }\end{array}$ & $\begin{array}{l}\uparrow \\
\text { Improved occupancy rates of } \\
\text { vehicles, reduced driven kilometres } \\
\text { and emissions, and cost-savings for } \\
\text { the public sector. }\end{array}$ & $\begin{array}{l}\uparrow \\
\text { Increased use of PT and } \\
\text { shared rides. }\end{array}$ \\
\hline & $\begin{array}{l}\text { Accessibility of the public } \\
\text { to transport services }\end{array}$ & $\begin{array}{l}\uparrow \\
\text { New door-to-door service } \\
\text { (no PT available). }\end{array}$ & $\begin{array}{l}\uparrow \\
\text { New door-to-door service for private } \\
\text { customers (no PT available). }\end{array}$ & $\begin{array}{l}\uparrow \\
\text { Single train/plane ticket with } \\
\text { last mile service. }\end{array}$ \\
\hline & $\begin{array}{l}\text { Modification of vehicle } \\
\text { fleet }\end{array}$ & $\begin{array}{l}0 \\
\text { Existing fleet utilized. New driver } \\
\text { software. }\end{array}$ & $\begin{array}{l}0 \\
\text { Existing fleet utilized. New driver } \\
\text { software. }\end{array}$ & $\begin{array}{l}0 \\
\text { Existing fleet utilized. New } \\
\text { driver software. }\end{array}$ \\
\hline & $\begin{array}{l}\text { Legal and policy } \\
\text { modifications }\end{array}$ & $\begin{array}{l}\text { n.a. } \\
\text { Need: interoperability of travel card } \\
\text { systems. }\end{array}$ & $\begin{array}{l}\text { n.a. } \\
\text { Need: GDPR interpretation guide. } \\
\text { Harmonized procedures for SHST. }\end{array}$ & $\begin{array}{l}\text { n.a. } \\
\text { Need: PT data in digital } \\
\text { format. }\end{array}$ \\
\hline
\end{tabular}


integrated gradually into the same system. These could include other public sector transport services such as school transportation, market-based services like travel chains including long-haul transport, and services offered by private people such as peer-to-peer car rental and ridesharing services. Inclusivity should be kept in mind when developing the services for various user groups. Future research should also include impact assessment in order to assist decision-making and further development, as well as share the lessons learned.

\section{Abbreviations}

$\mathrm{CO}_{2}$ : Carbon dioxide; DTR: Demand-Responsive Transport; GDPR: General Data Protection Regulation; KPI: Key performance indicator; MaaS: Mobility as a Service; PPP: Public-Private Partnership; PT: Public Transport; SHST: Social and Health Service Transport

\section{Acknowledgements}

The authors gratefully acknowledge the Finnish Innovation Fund Sitra for enabling and co-financing the study, as well as pilot regions and companies for conducting the pilots.

\section{Authors' contributions}

Jenni Eckhardt wrote the paper and Aki Aapaoja contributed to the paper structure. Jenni Eckhardt designed the analysis, and together with Arttu Lauhkonen collected the data. All the authors provided feedback and participated in the analysis of the results. The author(s) read and approved the final manuscript.

\section{Authors' information}

Jenni Eckhardt (jenni.eckhardt@vtt.fi) received her M.Sc. (Tech.) degree in 2002. She is currently working as a Research Team Leader and project manager at VTT Technical Research Centre of Finland Ltd. Her research interests include mobility services, logistics and transport emissions. She coordinated an international MaaS project, MAASiFiE, and leads national MaaS projects.

Arttu Lauhkonen (arttu.lauhkonen@vtt.fi) received his M.Sc. (Tech.) degree in 2016. He is working as a Research Scientist at VIT Technical Research Centre of Finland Ltd. Prior to joining VTT, Lauhkonen worked as an analyst and has experience in freight transportation cost and emission data. He has also worked as an advisor at the Finnish Transport Safety Agency (Trafi) on projects related to the road transportation business.

Aki Aapaoja (aki.aapaoja@vtt.fi) has a Ph.D. (2014) in Industrial Engineering and Management. Currently he is a Solution Sales Lead and is responsible for sales and customer partnerships for mobility and transport sectors at VIT Technical Research Centre of Finland Ltd. Prior to his current position, he gained extensive experience in business ecosystems and living labs, mobility services, construction industry, and automated and connected driving.

\section{Funding}

The research was co-funded by the Finnish Innovation Fund Sitra.

\section{Availability of data and materials}

The data that support the findings of this study are available from the pilot stakeholders, but restrictions apply to the availability of these data and are not publicly available. Data are, however, available from the authors upon reasonable request and with permission of the pilot stakeholders.

\section{Competing interests}

The authors declare that they have no competing interests.

Received: 6 April 2020 Accepted: 28 August 2020

Published online: 07 September 2020

\section{References}

1. Burrows, A., Bradburn, J., \& Cohen, T. (2015). Journeys of the future. Introducing mobility as a service. London: Atkins.
2. Eadie, R., Millar, P., \& Toner, L. (2013). Public private partnerships, reevaluating value for money. International Journal of Procurement Management, 6, 152-169. https://doi.org/10.1504/IJPM.2013.052467.

3. Eckhardt, J., Aapaoja, A., \& Haapasalo, H. (2020). Public-private-people partnership networks and stakeholder roles within MaaS ecosystems. In A. M. Amaral, L. Barreto, S. Baltazar, J. P. Silva, \& L. Gonçalves (Eds.), Implications of mobility as a service (MaaS) in urban and rural environments. Hershey: |G| Global. https://doi.org/10.4018/978-1-7998-1614-0.

4. Eckhardt, J., Aapaoja, A., Nykänen, L., Sochor, J., Karlsson, M., \& König, D. (2017). Deliverable 2: European MaaS Roadmap 2025. In MAASiFiE project funded by CEDR Retrieved from https:/www.vtt.fi/sites/maasifie/Publishinglmages/results/ cedr_mobility_MAASiFiE_deliverable_2_revised_final.pdf.

5. Eckhardt, J., Nykänen, L., Aapaoja, A., \& Niemi, P. (2018). MaaS in rural areas case Finland. Research in Transportation Business \& Management, 27, 75-83. https://doi.org/10.1016/j.rtbm.2018.09.005.

6. Eisenhardt, K. M. (1989). Building theories from case study research. Academy of Management Review, 14(4), 532-550.

7. ERTICO (2018). Mobility as a service - from modes to mobility. Brussels: ERTICO Retrieved from https://ertico.com/wp-content/uploads/2018/09/Ertico_ MaaS-vision-paper-2018_www.pdf.

8. European Commission. (2017). Smart, green and integrated transport, Horizon 2020 work programme 2016-2017. Retrieved from https://ec europa.eu/research/participants/data/ref/h2020/wp/2016_2017/main/h2020wp1617-transport_en.pdf

9. European PPP Expertise Centre (2015). PPP motivations and challenges for the public sector. Luxembourg: European Investment Bank.

10. European Union (2018). Public Private Partnerships in the EU: Widespread shortcomings and limited benefits (special report no 9/2018). Luxembourg: European Court of Auditors.

11. Finnish Environment Institute SYKE. (2014). Urban-rural classification. Retrieved from https://www.ymparisto.fi/fi-Fl/Elinymparisto_ja_kaavoitus/ Yhdyskuntarakenne/Tietoa_yhdyskuntarakenteesta/Kaupunkimaaseutu_ luokitus

12. Finnish Transport Agency (2017). Ylläs Around impact study (in Finnish). Research reports of the Finnish transport agency 31/2017. Helsinki: Finnish Transport Agency.

13. Gogola, M., \& Sitányiová, D. (2020). Innovative mobility solutions in rural areas with case studies. In A. M. Amaral, L. Barreto, S. Baltazar, J. P. Silva, \& L. Gonçalves (Eds.), Implications of mobility as a service (MaaS) in urban and rural environments: Emerging research and opportunities, (pp. 156-209). IGI Global: Hershey.

14. Grimsey, D., \& Lewis, M. K. (2005). Are public private partnerships value for money? Accounting Forum, 29(4), 345-378. https://doi.org/10.1016/j.accfor. 2005.01.001.

15. Heikkilä, S. (2014). Mobility as a Service - A Proposal for Action for the Public Administration: Case Helsinki. (Master's thesis). Retrieved from Aaltodoc database. (http://urn.fi/URN:NBN:fi:aalto-201405221895)

16. Hietanen, S. (2014). 'Mobility as a service' - The new transport model? ITS \& Transport Management Supplement, Eurotransport, 12(2), 2-4.

17. International Transport Forum (2015). International experiences on public transport provision in rural areas. Paris: International Transport Forum.

18. ITS Australia. (2018). Mobility as a service in Australia: customer insights and opportunities. Retrieved from https://www.its-australia.com.au/maasreport/.

19. Jittrapirom, P., Caiati, V., Feneri, A.-M., Ebrahimigharehbaghi, S., AlonsoGonzález, M. J., \& Narayan, J. (2017). Mobility as a service: A critical review of definitions, assessments of schemes, and key challenges. Urban Planning, 2(2), 13-25. https://doi.org/10.17645/up.v2i2.931.

20. Kamargianni, M., Matyas, M., Li, W., \& Schäfer, A. (2015). Feasibility study for "mobility as a service concept" in London. FS-MaaS Project - Final deliverable. London: UCL Energy Institute. Retrieved from https://www.ucl.ac.uk/bartlett/ energy/sites/bartlett/files/fs-maas-compress-final.pdf.

21. Kamargianni, M., Li, W., \& Matyas, M. (2016). A comprehensive review of "mobility as a service" systems. In Transportation Research Board 95th Annual Meeting 2016, (pp. 16-5401).

22. Karlsson, M., Sochor, J., Aapaoja, A., Eckhardt, J., \& König, D. (2017). Deliverable 4: Impact assessment. MAASiFiE project funded by CEDR.

23. König, D., Eckhardt, J., Aapaoja, A., Sochor, J., \& Karlsson, M. (2016). Deliverable 3: Business and operator models for MaaS. In MAASiFiE project funded by CEDR Retrieved from https://www.vtt.fi/sites/maasifie/ Publishinglmages/results/cedr_mobility_MAASiFiE_deliverable_3_revised final.pdf. 
24. Lucas, K. (2012). Transport and social exclusion: Where are we now? Transport Policy, 20, 105-113.

25. MaaS Alliance (2017). White paper. Guidelines \& Recommendations to Create the Foundations for a Thriving MaaS Ecosystem. Brussels: MaaS Alliance.

26. Moving Forward Consulting. (2016). HERMES - healthy, Safe and ecological road transport, Mobility and Energy use for better Sustainability in Finland with ITS-Intelligent Transportation Systems. Report prepared for the Ministry of transport and Communication (MINTC) Finland.

27. National Academies of Sciences, Engineering, and Medicine (2016). Shared Mobility and the Transformation of Public Transit. Washington, DC: The National Academies Press. https://doi.org/10.17226/23578.

28. Organisation for Economic Cooperation and Development. (2012). Recommendation of the council on principles for public governance of public-private partnerships. Author.

29. Polis (2017). Mobility as a service: Implications for urban and regional transport. Brussels: Polis.

30. Rezo Pouce. (2020). Rezo Pousse Médias et Presse. Retrieved May 11, 2020, from https://www.rezopouce.fr/page/Medias_et_Presse

31. Ryser, L., \& Halseth, G. (2012). Resolving mobility constraints impeding rural seniors' access to regionalized services. Journal of Aging \& Social Policy, 24(3), 328-344. https://doi.org/10.1080/08959420.2012.683329.

32. Smith, G., Sarasini, S., Karlsson, I. C. M., Mukhtar-Landgren, D., \& Sochor, J. (2019a). Governing mobility-as-a-service: Insights from Sweden and Finland. In M. Finger, \& M. Audouin (Eds.), The Governance of Smart Transportation Systems (chapter 9). The urban book series. Cham: Springer. https://doi.org/10. 1007/978-3-319-96526-0 9.

33. Smith, G., Sochor, J., \& Karlsson, I. C. M. (2019b). Public-private innovation: Barriers in the case of mobility as a service in West Sweden. Public Management Review, 21(1), 116-137. https://doi.org/10.1080/14719037.2018. 1462399.

34. Sochor, J., Karlsson, M., \& Strömberg, H. (2016). Trying out mobility as a service: Experiences from a field trial and implications for understanding demand. Transportation Research Record: Journal of the Transportation Research Board, 2542, 57-64. https://doi.org/10.3141/2542-07.

35. The Finnish Innovation Fund Sitra. (n.d.). Public and private mobility services to be offered side by side. Retrieved from https://www.sitra.fi/en/projects/ public-private-mobility-services-offered-side-side/\#what-is-it-about

36. Titheridge, H., Christie, N., Mackett, R., Hernández, D. O., \& Ye, R. (2014). Transport and poverty: a review of the evidence. (UCLTI publications). London: UCL transport institute, University College London.

37. Transport Systems Catapult (2016). Exploring the opportunity for mobility as a service in the UK. Milton Keynes: Transport Systems Catapult.

38. Van Ham, H., \& Koppenjan, J. (2001). Building public-private partnerships: Assessing and managing risks in port development. Public Management Review, 3(4), 593-616. https://doi.org/10.1080/14616670110070622.

39. Yin, R. K. (2003). Case study research: Design and methods, (3rd ed.). Beverly Hills: SAGE Publications.

\section{Publisher's Note}

Springer Nature remains neutral with regard to jurisdictional claims in published maps and institutional affiliations.

\section{Submit your manuscript to a SpringerOpen ${ }^{\circ}$ journal and benefit from:}

- Convenient online submission

- Rigorous peer review

- Open access: articles freely available online

- High visibility within the field

- Retaining the copyright to your article

Submit your next manuscript at $\boldsymbol{\nabla}$ springeropen.com 